\begin{tabular}{|l|l|l|}
\hline \multicolumn{2}{|c|}{ PublisherInfo } \\
\hline \hline PublisherName & $:$ & BioMed Central \\
\hline \hline PublisherLocation & $:$ & London \\
\hline \hline PublisherImprintName & $:$ & BioMed Central \\
\hline \hline
\end{tabular}

\title{
Plant-pathogen interactions
}

\begin{tabular}{|l|l|l||}
\hline \multicolumn{2}{|c|}{ ArticleInfo } \\
\hline \hline ArticleID & $:$ & 3639 \\
\hline \hline ArticleDOI & $:$ & $10.1186 /$ gb-2000-1-2-reports0062 \\
\hline \hline ArticleCitationID & $:$ & reports0062 \\
\hline \hline ArticleSequenceNumber & $:$ & 36 \\
\hline \hline ArticleCategory & $:$ & Paper report \\
\hline \hline ArticleFirstPage & $:$ & 1 \\
\hline \hline ArticleLastPage & $:$ & 4 \\
\hline \hline & & RegistrationDate : 2000-6-27 \\
ArticleHistory & $:$ & Received $\quad$ 2000-6-27 \\
& $:$ OnlineDate $2000-7-19$ \\
\hline \hline ArticleCopyright & $:$ & BioMed Central Ltd2000 \\
\hline \hline ArticleGrants & $:$ & \\
\hline \hline
\end{tabular}




\begin{tabular}{|l|l|l|}
\hline ArticleContext & $:$ & 130591122 \\
\hline
\end{tabular}

\section{Thomas Eulgem}

\section{Abstract}

Early response genes encoding potential regulators of pathogen and wound-induced plant responses have been identified using gene expression profiling.

\section{Significance and context}

Plants can specifically recognize distinct races of pathogenic microorganisms and can respond with appropriate defense measures. Such race-specific resistance requires a complementary pair of genes consisting of a plant resistance $(R)$ gene and an avirulence (Avr) gene of the pathogen. Their products are thought to be directly involved in the recognition event that triggers resistance. One of the earliest defense responses of plants is the generation of active oxygen species (AOS, oxidative burst), which can be detected in cell culture systems within a few minutes after pathogen recognition. Besides having toxic effects on the invading pathogen, AOS appear to play a role in signaling. Defense-associated activation of numerous genes has been previously demonstrated to be dependent on the oxidative burst.

Using cDNA amplified fragment length polymorphism (AFLP), Durrant et al. have for the first time comprehensively examined early gene expression changes, which are independent of the oxidative burst, induced during a race-specific plant pathogen interaction. By choosing a time window that covers the first 30 minutes after pathogen recognition, they focused exclusively on early response genes, some of which may encode regulators of successive defense responses, including the oxidative burst.

\section{Key results}

The tomato $R$ gene $C f 9$ confers resistance to races of the fungal pathogen Cladosporium fulvum expressing the $A v r 9$ avirulence gene. A cDNA-AFLP-based RNA fingerprinting analysis was applied to cultured tobacco cells that contain $C f 9$ as a transgene, 30 minutes after treatment with recombinant Avr9 protein. Based on non-selective amplification of cDNA fragments representing cellular mRNAs, this method allows gene expression profiling which requires, in contrast to cDNA microarrays, no prior assumptions about the set of genes that might be affected.

Using 512 primer combinations, approximately 30,000 AFLP fragments were visualized. The authors estimate that this may represent more than $75 \%$ of all tobacco transcript species. Differential expression 
in response to Avr9 could be observed for 290 of these fragments (in 273 cases expression was upregulated). The genes represented by these fragments were named $A C R E$ (Avr9/Cf9 rapidly elicited) genes. Application of a specific inhibitor of the oxidative burst, diphenyleneiodonium, showed that only $4 \%$ of the early expression changes are dependent on AOS. Furthermore, Avr9-induced expression seems, at least in some cases, to be independent of de novo protein biosynthesis, as determined by experiments with the translation inhibitor cycloheximide. Only 42 ACREs show similarity to known genes. A subset of these encodes potential regulatory proteins, such as protein kinases, protein phosphatases and transcription factors including EREBPs (ethylene response element binding proteins) and one member of the WRKY family, a large class of plant-specific zinc finger-type transcriptional regulators that bind to $\mathrm{W}$ box cis-elements. As previously demonstrated, members of both transcription factor families appear to participate in the regulation of transcriptional responses associated with pathogen resistance. A small fraction of the $A C R E$ genes were also shown to be activated in intact leaf tissue in response to wounding. These findings are consistent with previous investigations, and suggest an overlap between pathogen- and wound-induced plant responses.

\section{Conclusions}

The majority of early gene regulatory events triggered by Avr9 in $C f 9$ tobacco cell cultures are independent of AOS. Unlike many other defense responses, $A C R E$ gene expression must therefore be controlled by a regulatory pathway that operates independently of the oxidative burst. Alternatively, this pathway could act causally upstream of AOS production. Furthermore, as shown for a subset of $A C R E$ genes, transcriptional responses triggered by race-specific pathogen recognition and wounding can overlap.

\section{Reporter's comments}

By defining a large class of AOS-independent, early pathogen response genes, this study certainly contributes to our current understanding of defense-associated gene regulation in plants. Most importantly, however, it constitutes a starting point for future investigations. As the authors suggest, the role of distinct $A C R E$ genes in the plant defense response should be addressed using reverse genetics, and investigation of regulatory mechanisms underlying $A C R E$ gene activation could reveal common principles in the specific expression control of these genes. I think, however, that the overlap in early Avr9 and wound-induced gene expression, which is strongly emphasized in the paper's title, was somewhat neglected in this study. Only a limited set of $18 A C R E$ genes was tested after wounding. This comparison of expression changes should be extended in the future to define sets of genes that are specifically activated in response to each of these stimuli.

\section{Table of links}


Plant Cell

\section{References}

1. Durrant WE, Rowland O, Piedras P, Hammond-Kosack KE, Jones JDG: cDNA-AFLP reveals a striking overlap in the race-specific resistance and wound response expression profiles. Plant Cell. 2000, 12: 963-977. 1040-4651 